\title{
Grain Legumes in Nepal: Present Scenario and Future Prospects
}

\author{
Gharti DB ${ }^{1, *}$, Darai R. ${ }^{1}$, Subedi $\mathbf{S}^{1}$, Sarker A. ${ }^{2}$, Shiv Kumar ${ }^{3}$ \\ ${ }^{1}$ Grain Legumes Research program, Rampur, Chitwan, Nepal \\ ${ }^{2}$ South Asia and China Regional Program, International Center for Agricultural Research in the Dry Areas (ICARDA), New Delhi, \\ India \\ ${ }^{3}$ North Africa Platform, ICARDA, Rabat, Morocco \\ *Corresponding author: dhana_gharti@yahoo.com
}

Received August 12, 2014; Revised September 10, 2014; Accepted September 18, 2014

\begin{abstract}
Grain legumes play an important role in Nepalese agriculture contributing towards food and nutritional security, nitrogen economy, crop intensification, diversification and sustainable farming systems and rank fourth in terms of area and fifth in agricultural production. Grain Legumes Research program (GLRP) of Nepal in collaboration with CGIAR centers works for genetic improvement of lentil, chickpea, pigeonpea, soybean, mungbean, blackgram, and cowpea, resulting in development of 35 improved varieties and a dozen of production technologies for different agro-ecological domains. This has led to substantial increase (142\%) in grain legumes production, mainly because of $47 \%$ area increase and $65 \%$ yield increase during the last two and a half decades. The current estimates for area, production and productivity of grain legumes in Nepal are 334,323 ha, 319,770 metric tons and $956 \mathrm{~kg}$ ha-1, respectively. Lentil is the major grain legume and accounts for $62 \%$ of area and $65 \%$ production of total grain legumes in Nepal and has emerged as an important export commodity. A number of micronutrient rich (iron, zinc and selenium) lentil lines have been identified in collaboration with ICARDA and scaled out under the Harvest Plus Challenge Program. Further efforts are underway for expanding area under lentil, chickpea, fieldpea, and lathyrus in rice-fallow through Village based seed enterprise under OFID/ICARDA program. There is further scope for increase in area, production and productivity of grain legumes in Nepal through development and popularization of suitable varieties and technologies, streamlining community based seed production system, addressing climate change issues and policy reforms for the promotion of legumes.
\end{abstract}

Keywords: Grain legumes, Nepal, food security, variety development, biotic constraints

Cite This Article: Gharti DB, Darai R., Subedi S, Sarker A., and Shiv Kumar, "Grain Legumes in Nepal: Present Scenario and Future Prospects." World Journal of Agricultural Research, vol. 2, no. 5 (2014): 216-222. doi: 10.12691/wjar-2-5-3.

\section{Introduction}

Grain legumes play an important role in Nepalese agriculture contributing towards food and nutritional security, nitrogen economy, crop intensification, diversification and sustainable farming systems. Grain legumes rank fourth in terms of acreage (about $10.8 \%$ of total cultivated land) and $5^{\text {th }}$ in production. Grain Legumes Research program (GLRP) of Nepal in collaboration with CGIAR centers works for genetic improvement of lentil, chickpea, pigeonpea, soybean, mungbean, blackgram, grasspea, fababean and cowpea. Lentil is the main pulse crop in Nepal $(62 \%$ area and 64\% production of the total legume (MOAD 2012). It is recognized as one of the major agricultural produce among 12 goods with high export potential and medium socio-economic impacts by Nepal Trade Integration Strategy (NTIS) (MoCS, 2010). Lentil alone contributes about 2.3 percent of total national exports and shares about 3.1 percent of the total lentil export in the world (USAID, 2011)

\section{Trends in Area, Production and Productivity}

Grain legumes research for development has led to substantial increase (142\%) in grain legumes production, mainly because of $47 \%$ area increase and $65 \%$ yield increase during the last two and a half decades (Figure 1). The current estimates for area, production and productivity of grain legumes in Nepal are 334,323 ha, 319,770 metric tons and $956 \mathrm{~kg} \mathrm{ha}^{-1}$, respectively. Area, production and productivity of lentil have been increased by $111 \%, 257 \%$ and $69 \%$, respectively in between 1985/86 and 2012/13 (Figure 2). Lentil is the major grain legume and accounts for $62 \%$ of area and $65 \%$ production of total grain legumes in Nepal (Figure 3) and has emerged as an important agricultural export commodity. Recognized as one of the the major agricultural product among 12 goods with high export potential and medium socioeconomic impacts by Nepal Trade Integration Strategy (NTIS) (MoCS, 2010). 
Nepal exports both whole and split lentils. Lentils are grown in terai, inner terai and mid hills of the country. The cultivation of lentil has been increasing because of its increasing preference for its internal consumption and potential for export market. Nepalese lentils have greater demand in the international market. Bangladesh, Singapore, Sri Lanka, Germany, Korea, UK, Indonesia are its major export markets. Soybean is identified as the industrial crop and important ingredient for poultry industry. Winter grain legumes crops such as lentil, chickpea, Kidney bean, grasspea, fieldpea and fababean are grown entirely dependent on residual soil moisture after the harvest of rice (post rice) or seed broadcasted on standing rice about 7-15 days prior to rice harvest (relay cropping). While warm season grain legumes like soybean, mungbean, cowpea, blackgram and pigeonpea are grown during summer month (monsoon rain) in mono, mixed with maize/ finger millet or on paddy bunds.

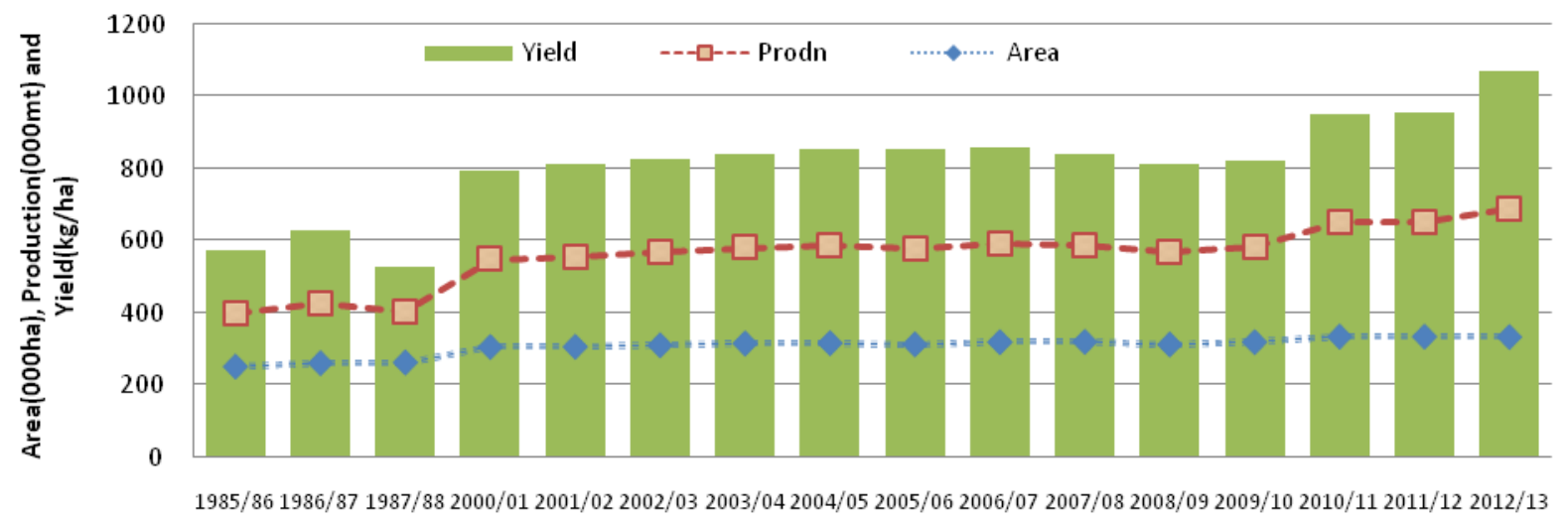

Figure 1. Ttrends in area, production and productivity of Grain legumes (1985-2012)

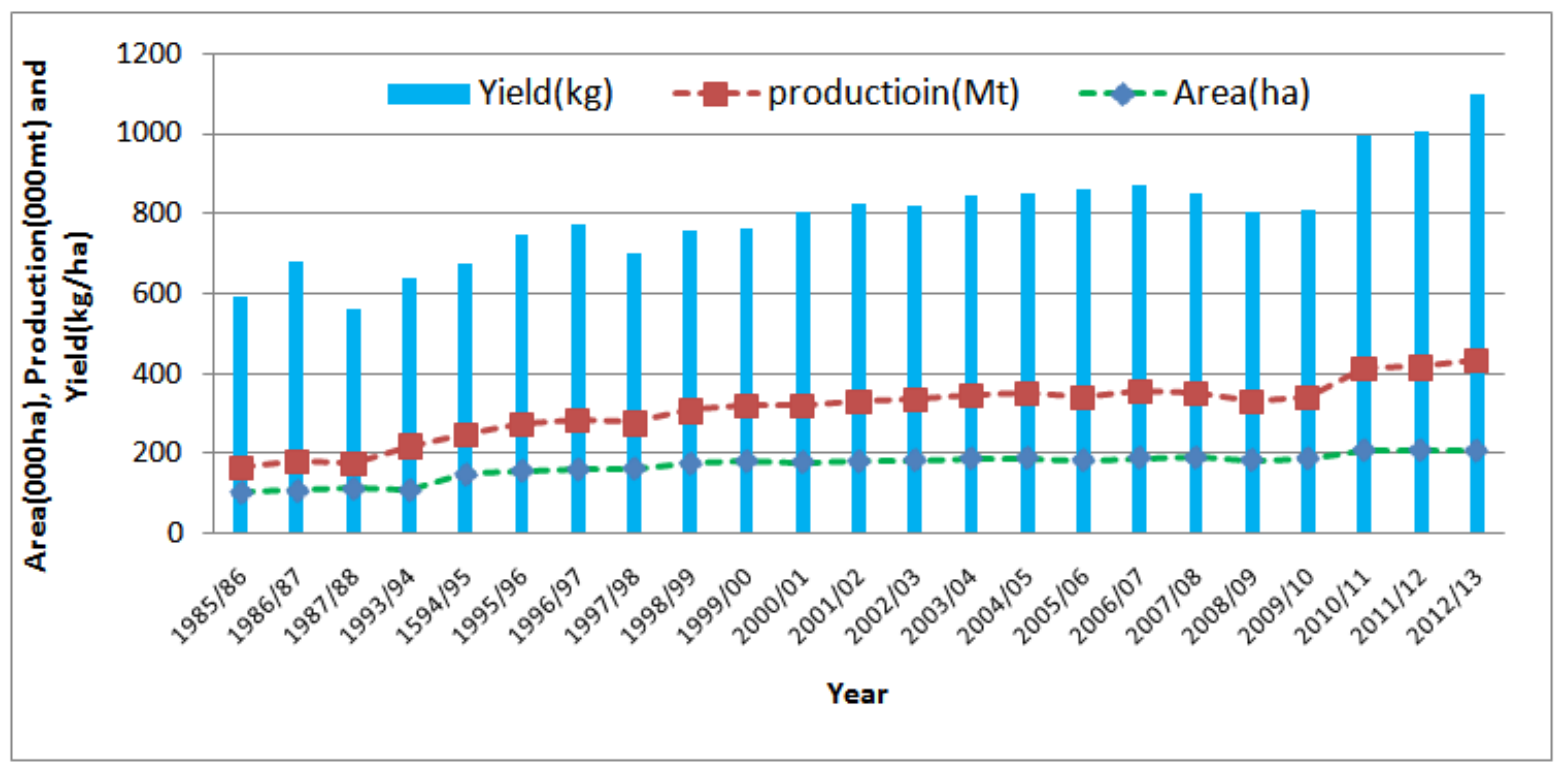

Figure 2. Trends in Area, production and productivity of lentil over the years (1985-2012)
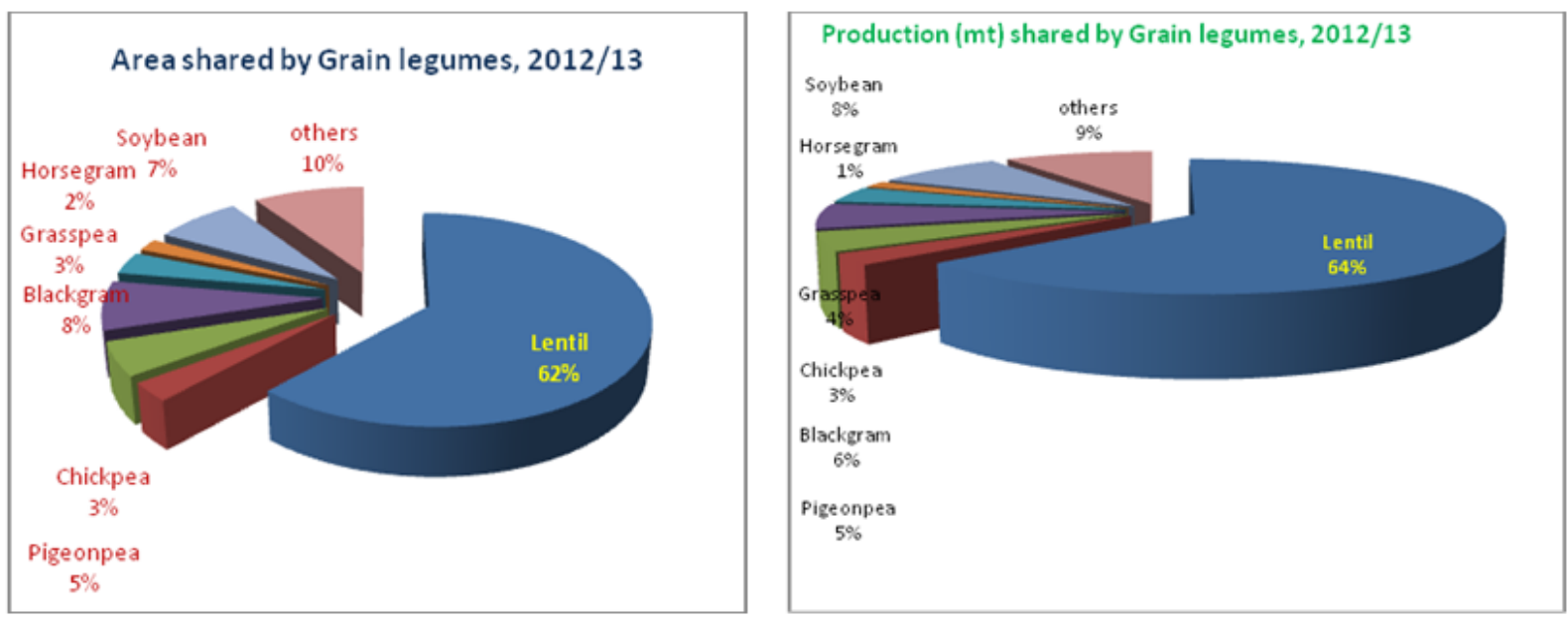

Figure 3. Area and Production Scenario of Grain Legumes in Nepal, 2012/13 


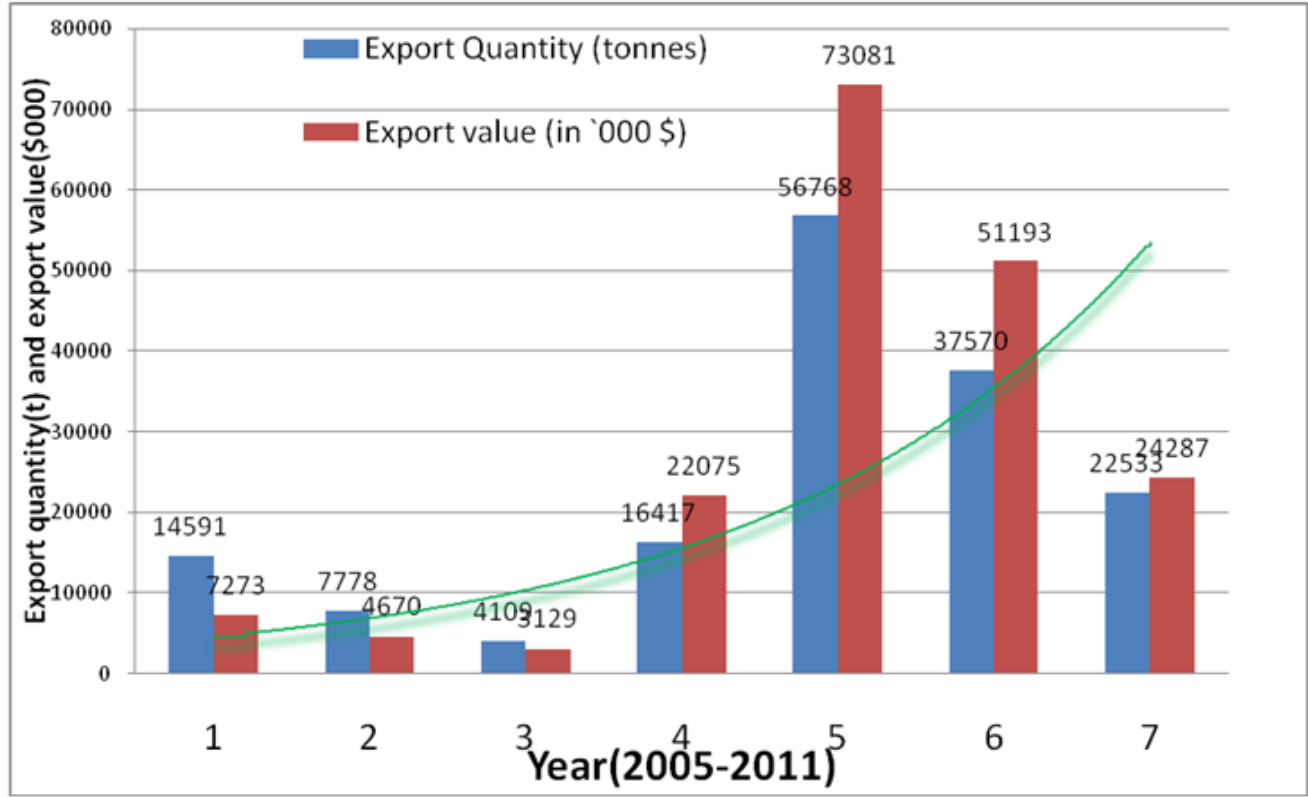

Figure 4. Export quantity and Export value of lentil from Nepal

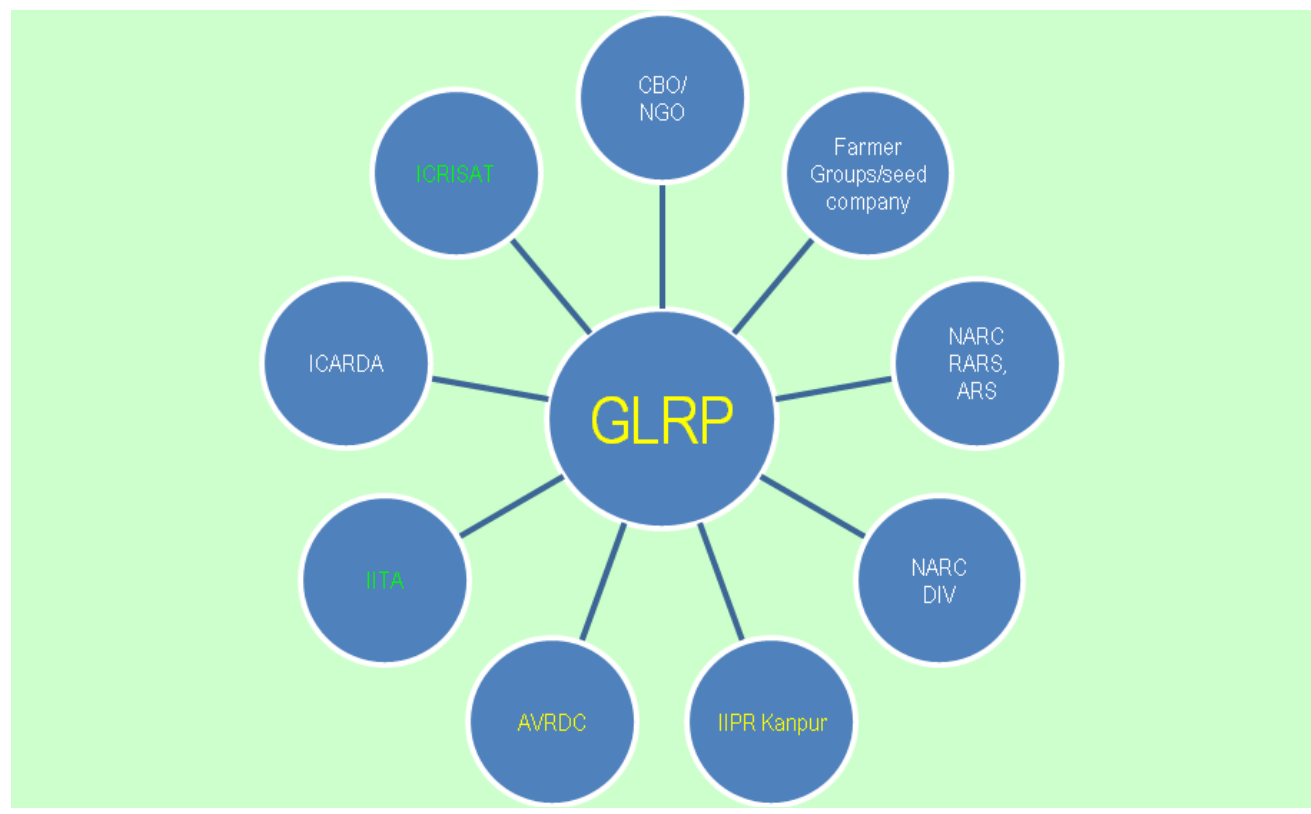

Figure 5. Linkages and Collaboration

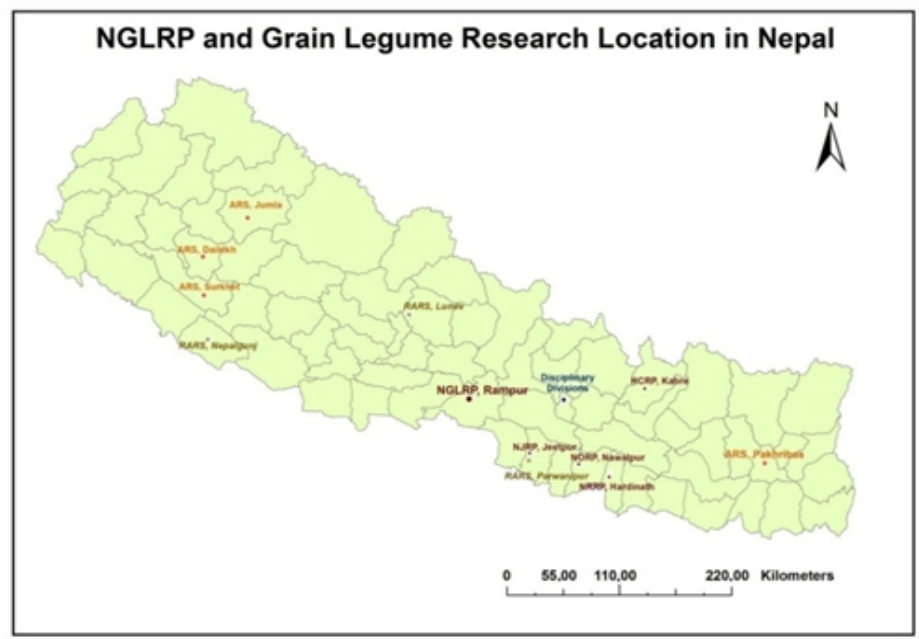

ARS Jumla (2387 m) RARS Nepalgunj $(190 \mathrm{~m})$ ARS Dailekh ARS Surkhet $(450 \mathrm{~m})$ RARS Lumle (1678 m) NGLRP Rampur (228 m) AGD/PPD Khumaltar (1360 m) RARS Parwanipur (115 m) JRP Jitpur NORP Sarlahi (144 m) ARS Pakhribas $(1760 \mathrm{~m})$ NRRP Hardinath $(90 \mathrm{~m})$ RARS Tarahara (200 m) 
Rampur, headquarters of Grain Legumes Research Program, is centrally located in Nepal: $27^{\circ} 40^{\prime} \mathrm{N}$ latitude, $84^{\circ} 19^{\prime}$ E longitude, $156 \mathrm{~km}$ from Kathmandu, Altitude 228 masl).

\section{Research Accomplishments}

Research activities at NGLRP are variety development, crop management, research outreach, source seed production and dissemination of technologies. NGLRP has been working in collaboration with national (Department of Agriculture, NGO, community based organizations, seed companies etc) and international organizations/NARS such as ICARDA, ICRISAT, IVRDC, ACIAR/CLIMA, IITA, BARI etc. for germplasm exchange, technology generation, funding, technical support (including expert visits) and capacity building. Grain legume improved technologies have been developed in collaboration with various research and extension partners including valuable support from farmers.

\section{Germplasm Collection and Evaluation}

Collection mission had been undertaken at different occasions. In 1987, the first local collection was organized as a multi-crop expedition with supports from IDRC, Canada. Local landraces were collected from central to the western Nepal. A year later collections were made from central to the eastern terai through supports from USAID. In 1995, grain legumes were collected throughout the terai and inner terai regions as organized jointly by GLRP, CLIMA and ICARDA (Robertson et. al., 1995). At present a total of 2936 accessions of different grain legume crops are maintained at National Agriculture Genetic Resources Center (NAGRC), Khumaltar under Nepal Agricultural Research Council. Local materials have been collected from 66 districts representing terai, mid hill and high hills of Nepal.

\section{Varietal Improvement}

A total of 35 varieties of grain legumes have been released for general cultivation. In winter food legumes, ten lentil and eight chickpea varieties have been recommended. Lentil varieties released are from selections of local landraces (Sindur), selection of South Asian origin introduced either from India (Simrik. Sisir, Simal, Shital, Khajura Masuro-1) or from ICARDA (Sikhar, Khajura Masuro-2). However, the recently released varieties Sagun and Maheswor Bharati are from crosses made using lentils from South Asia and West Asia. These varieties have 40-60\% higher yield and 20-30\% larger seed size as compared to released variety Shital/Simal, moderately tolerant to Stemphylium blight and wilt disease. In chickpea, seven varieties released so far are of desi type and one Kabuli (Koseli). Among the summer legumes eight varieties of soybean, two varieties of pigeonpea, three varieties each of mungbean and cowpea, and one variety of blackgram had been released for general cultivation. A number of micro-nutrient rich (iron, zinc and selenium) lentil lines have been identified in collaboration with ICARDA and University of Saskatchewan and scaled out under the Harvest plus Challenge Program.

\section{Research Achievements in Lentil}

- Bio-fortified lentil cultivars identified: Lab analysis report indicated that Iron rich cultivars were PL4 (83.82 ppm), ILL9926 (79.18), LG12 (79.04), ILL7715 (78.59), ILL3490 (78.44), Shital (76.79), WBL77 (76.36), Zinc rich cultivars were LG12 (48.14 ppm), PL4 (47.9), ILL9926 (47.89), Shital (47.86), ILL6467 (47.38), ILL7715 (46.83) and selenium rich lentil cultivars were ILL6256 (0.42 ppm), Shital (0.41), Sagun (0.362), ILL6467 (0.35), HUL57 (0.34), ILL3490 (0.32)

- Bio-fortified lentil cultivars scaled up in 5000 farmers' field of different districts and farmers trained in value addition.

- Several lentil genotypes identified tolerant to stemphylium blight and wilt/root rot complex diseases.

- Stemphylium blight resistant/tolerant lentil genotypes identified: Genotypes ILL 2373, ILL 1704, X 9383, ILL 1672, ILL 2573, ILL 6256, NR 99S95-2-4, IL-1, ILL 6818, ILL 7538, 39S-66L, RL39, ILL 10134, RL 69, FLIP 2009-59 L, ILL 8009, RL-70, RL-75, RL-79 were found moderately tolerant to the disease.

- Wilt/ root resistant lentil genotypes identified: Genotypes ILL 590, ILL 1672, Bari Masur-4, FLIP 2008-71, ILL 6025, ILL 9993, ILL 7723, Aurun, RL28, Maheshwar Bharati, RL-39 and RL-62 were found moderately resistant to the disease

- The highest disease severity was recorded in the lentil plants sown on $21^{\text {st }}$ November i.e. 7 while lower disease severity was found on $11^{\text {th }}$ November sowing i.e. 3.00(1-9 scale).

- Botanical pesticides Bojho (Acorus calamus L.) and Timur (Xanthoxylum armatum DC) were effective botanicals to manage Stemphylium blight under both laboratory and field conditions.

- Pre-emergence application of Stomp 30EC (Pendimethalin) @ 2.5-3 ml/L water is effective in controlling weeds during early stage of crop growth.

- In lentil, the optimum sowing times are $2^{\text {nd }}$ to $4^{\text {th }}$ week of Nov and $2^{\text {nd }}$ to $4^{\text {th }}$ week of Oct in terai and mid-hill, respectively.

- In rice relay system, seed is broadcasted at 1-2 weeks prior to paddy harvest.

- Lentil seed priming with water up to $12 \mathrm{hrs}$ followed by 2 hrs air drying prior to sowing gave more yield (grain yield up to $2.9 \mathrm{t} / \mathrm{ha}$ in Simrik \& $2.8 \mathrm{t} / \mathrm{ha}$ in Sindur), one week earlier in maturity $\&$ robust seed over non priming. Mean yield increment of primed seed was $26 \%$ over the non-primed seed in the farmers' field

- $30 \mathrm{~kg}$ lentil seed and $2 \mathrm{~kg}$ seed of mustard per ha or $20 \mathrm{~kg}$ lentil seed and $6 \mathrm{~kg}$ seed of mustard per ha was the best seeding ratio for realizing higher yield and profit from mixed cropping under rainfed condition 
Table 1. Lentil varieties released in Nepal by national seed board

\begin{tabular}{|c|c|c|c|c|c|}
\hline Name & Acc \# & Origin & Source & Year & Domain \\
\hline Sindur & Lo-111-25 & Nepal & Nepal & 1979 & Terai, mid-hill \\
\hline Sisir & P43 & India & ICARDA & 1979 &, \\
\hline Simrik & T36 & India & ICARDA & 1979 & $"$ \\
\hline Sikhar & ILL 4404 & Pakistan & ICARDA & 1989 & $"$ \\
\hline Simal & LG 7 & India & ICARDA & 1989 & $"$ \\
\hline KhajuraMasuro 1 & LG 198 & India & ICARDA & 1999 & Western terai \\
\hline KhajuraMasuro 2 & PL 639 & India & ICARDA & 1999 &, \\
\hline Shital & ILL 2580 & India & ICARDA & 2004 & Terai, mid-hill \\
\hline Sagun & ILL 6829 & ICARDA & ICARDA & 2009 & Mid-hill, Valley \\
\hline MahesworBharati & ILL 7982 & ICARDA & ICARDA & 2009 & " \\
\hline
\end{tabular}

\section{Research Achievements in Chickpea}

- Till date eight chickpea varieties have been released for different agro-ecological domains, of which six cultivars are derived from ICRISAT

- Desh (7): Dhanush, Trishul, Sita, Radha, Kalika, Avrodhi, Tara (Derivative of a cross between local land race Dhanush $X$ K850)

- Kabuli (1): Kosheli

- Promising cultivars :KPG-59, KPG173-4, ICCV97207, ICCX840508-40, ICCX840508-44, ICCV05532, ICCX840508-44, ICCX840508-33 and ICCV87312

- Genotypes / varieties identified for Wilt complex resistance : ICCV03107, ICCV03213, ICCV04105, ICCV04106, ICCV05109, ICCV05110, ICCV92337, ICCV93207, ICCV95432, ICCV03111, KPG59, Tara, Avrodhi

- In chickpea, seed soaking in $0.05 \%$ sodium molybdate solution followed by treatment with Rhizobium@3 g/kg seed increased the nodulation and grain yield by $39 \%$ and $21 \%$, respectively.

- In chickpea, seed priming is very useful to establish plant stand in rice fallows. On an average of $41 \%$ yield increase was recorded from seed priming only.

\section{Research Achievements in Kidney bean}

- Promising kidney bean genotypes Amber, PDR 14 and Utkarsa were good yielders (1450-1700 kg/ha) in Rampur and Utkarsha, Parwanipur-1, Parwanipur-2, Amber and PDR 14 (about 3 t/ha) at Parwanipur.

- PDR 14 was also identified as moderately tolerant to white mold disease.

- Kidneybean genotypes PB0002 and PB0048 are high yielding and promising both for green pods and dry seeds for growing as a rainy season crop in the mid to high hills of mid/far western regions.

\section{Research Achievements in Grasspea}

- Low ODAP $(<0.04 \%)$ containing lines CLIMA Pink, 19B, 20A and Bari 2 were promising in terms of grain yield.

- Grasspea genotypes Sel-1959, Sel-290, Sel-2119, Sel-2177, Sel-387, Sel-299, Sel-449 and Sel-1942 showed good forage value.

\section{Research Achievements in Soybean}

- Promising genotypes LS-77-16-16, Kavre local, F778817, TGX-311-23D and IARS-87-1, IangBeakong, G 4504 and G 1871 (grain yield of 1.5 to $2.0 \mathrm{t} / \mathrm{ha}$ ).

- Genotypes CM 9125, G 8754, LS-77-16-16 and SB0065 were resistant to mungbean yellow mosaic virus (MYMV).

- 2:1 (soybean at both sides of maize rows spaced at 1 $\mathrm{m}$ apart with or without topping of maize plant at physiological maturity) and 1:2 (single row of soybean between 2 rows of maize spaced $1 \mathrm{~m}$ apart) were superior than local method (1 row of soybean in between 2 maize rows

\section{Research Achievements in Cowpea}

Dual purpose types: IT98K205-8, IT83S 899, IT86F2062-5-PKR, IT86F-2062-5 White and IT86F-2089-5 (green tender long pod, released as Malepatan-1).

\section{Research Achievements in Mungbean}

- Mungbean is a short duration legume, thrives well in various cropping system of Nepal and it is grown in rainy and spring seasons both. However, spring mungbean in rice-wheat-mungbean pattern is gaining popularity in recent years.

- It was estimated that about 400 thousand ha lands remain fallow after wheat harvest and before transplanting of monsoon rice in Nepal. Mungbean can be successfully integrated as catch or filler crop and provides additional income and food security to the farmers.

- Being a legume crop, it also improves soil health through atmospheric nitrogen fixation and addition of green biomass which is ultimately beneficial to the succeeding crop (mainly rice).

- Now, breeding strategies are directed to develop high yielding, synchronous maturity, better quality varieties combined with mungbean yellow mosaic virus (MYMV) and cercospora leaf spot (CLS) resistance and having wider adaptability.

- Till date three mungbean varieties i.e. Pusa Baisakhi, Pratikshya and Kalyan have been released for general cultivation in different domains of the country. Two superior genotypes introduced from IVRDC were released in the name of Pratikshya and Kalyan. These lines are characterized by semi synchronous maturity (85\% pod harvested after two pickings), resistant to MYMV and CLS and adapted to the rice based and maize based system.

- Some promising genotypes VC 6173(B-10), VC 6368 (46-40-4), NIMB101, Bari mung and VC $6153 \mathrm{~B}-20 \mathrm{G}$ had about $25 \%$ higher grain yield and $10-50 \%$ larger seed size as compared to Saptari Local (maturity about 65 days). Bari mung and NIMB 101 are resistant to MYMV. 
- In mungbean, supplementation of molybdenum through seed priming $(0.5 \mathrm{~g} / \mathrm{kg}$ seed $/ \mathrm{L}$ water for 4-6 hours) protected the crop from moisture stress and increased nodulation and grain yield

\section{Research Achievements Blackgram}

in

- High yielding genotypes identified were; BLG00032-1 (Nepal), BLG0067-1 (Nepal), BLG0072-1 (Nepal), BLG0076-2 (Nepal), BLG0068-2 (RU 54 Bangladesh) and BLG0069-1 (RU 34 Bangladesh) with mean grain yield ranging between 500 and 1270 $\mathrm{kg} / \mathrm{ha}$.

- Genotypes BLG0055-1-1, BLG0076-2, BLG0072-1, BLG0067-1 Bari Mash-1, Bari Mash-2 and Bari Mash-3 were found moderately resistant to MYMV.

- Black gram + Niger (2:1) row ratio with $40 \mathrm{~cm}$ row spacing was the most suitable row ratio for high yield $(1.32 \mathrm{t} / \mathrm{ha})$

\section{Research Achievements in Pigeonpea}

- ICPL86005 was good performer in central terai.

- Extra-short duration variety ICPL88039 promising for growing in pigeonpea-wheat rotation and also on the edges of terraces in the hills of mid-western Nepal.

- Long duration vegetable type variety ICP7035 is resistant to both Fusarium wilt and Sterility mosaic disease (SMD) and is suitable for inclusion in agroforestry system in the terai and low hills.

- Pigeonpea + maize intercropping in 1:1 or 1:2 row ratio (Pigeonpea varieties Rampur Rahar-1, ICPL86005, Pusha-9, Pusha-14 and ICPL88039).

\section{Other Achievements}

Efforts are underway for expanding area under lentil, chickpea, fieldpea, and grasspea in rice-fallow through intensification of rice-fallows with pulse as a second crop, capacity building of farmers and other stakeholders, village based seed enterprise development under OFID/ICARDA program.

\section{Constraints to Grain Legumes Production}

- Bitotic stresses

- Diseases

- Insect-pests

- Weeds

- Low priority in National policy

- Secondary crops - rainfed, marginal land

- Global warming/ climate change -

- high risk in production due to severe drought
- Shortening of crop duration (in particular winter crops in terai)

- Terminal heat

- Change in pests/ diseases dynamics

- Degradation of soil by unbalanced use of chemical fertilizers in cereal mono culture (rice, wheat, maize)

- Nutrient mining and soil acidity

- Grown entirely on residual soil moisture/ rainfall

- Severe drought/ erratic rainfall

- Lack of input responsive varieties

- Lack of mechanization

- Unavailability of quality seed/ lack of organized seed production and marketing.

- Lack of systematized marketing

- High Genotype x Environment interaction (nonavailability of location/farming system specific varieties)

\section{Future Research for Development Strategies}

- Varietal development using local landraces and introduction of exotic materials (selection/Hybridization)

- Improved methodologies and tools for genetic improvement (pre-breeding, advanced biometry, international crop information system, etc.).

- Integrated pest management (IPM) options for the control of diseases, insect pests and parasitic weeds.

- Mutation breeding

- Use of molecular tools to asses variation for high yielding cultivar development

- Focus on exportable qualities like small seeded, red cotyledon and tasty lentil (Quality breeding)

- Plan for adequate quality source seed production within the NARC stations and through cooperatives/seed growers

- Initiate breeding program on GL for stress tolerance (diseases, pests, drought and cold) (identify QTL in the context to climate change, drought etc)

- Crop simulation modeling on pulse crops to predict the crop productivity and sustainable use of water and other resources

- High yielding short duration varieties of lentil ,mungbean and chickpea fitting into short windows available between the two main crops in southern latitudes.

- Bio-fortified lentils (HarvestPlus) and low-toxin grasspea for improved nutrition and health.

- Strengthening seed delivery systems.

- Capacity building in NARS programs.

- Develop suitable technology for stress environments

- Need for revision on macro and micro-nutrients (B, Mo, S, Zn) requirements

- Standardize the foliar spray of urea for balanced nutrition

- Weed management

- Integrated approach

- Post emergence herbicide in particular for relay lentil/ conservation agriculture based farming

- Conservation agriculture 
- Residue management practices

- Enhance productivity and water use efficiency in pulses through raised bed/ridge planting technique

- Uptake pathways for the low cost (RCT technologies)

- Socio-economic and policy issues for increasing pulses productivity and sustainability

\section{Conclusion}

Grain legumes research for development in Nepal in collaboration with various international and national agricultural research organizations has led to the release of 35 grain legume varieties and popularization of several production technologies ultimately resulting into a substantial increase (142\%) in grain legumes production, mainly because of $47 \%$ area increase and $65 \%$ yield increase during the last two and a half decades. Nepal has a great potential to produce different grain legume species because of her diverse agro-ecological environments. She still holds about 0.24 million hectares of rice-fallows having a great opportunity to incorporate grain legumes in the rice based cropping system and hence there is further scope to increase area, production and productivity of grain legumes through development and popularization of suitable varieties and technologies, streamlining community based seed production, addressing climate change issues and policy reforms for the promotion of grain legumes.

\section{Acknowledgements}

The authors are grateful to ICARDA,ICRISAT, IVRDC, IITA, ACIAR/CLIMA, IIPR (India) and BARI (Bangladesh) for providing valuable research materials and technical support. The authors would like to extend sincere gratitude to the University of Saskatchewan, Canada (Prof. Bert Vandenberg) for micro-nutrient analysis of Nepalese lentil. We also would like to express thanks to NARC management for their keen interest and strong support to the program.

\section{References}

[1] Bharati MP and RK Neupane (1989) Lathyrus sativus cultivation and screening of the germplasm in Nepal. In the Grasspea Threat and Promise: Proceedings of International Network for the Improvement of Lathyrus sativus and the Eradication of lathyrism. Lathyrism (eds P Spencer), Third World Medical Research Foundation, New York, pp 159-167.

[2] FAOSTAT (2013) FAO Statistics Division 2011.

[3] Furman BJ, Adhikary P, Bharati M, P, (1988) 'Collection of Lens culinaris Medik Germplasm in the eastern Terai Region of Nepal 1988.' (National Agriculture Research and Services Center, National Grain Legumes Improvement Program: Kathmandu, Nepal)

[4] MoAC (2011) Statistical information on Nepalese Agriculture 2008/09. Agri-Business Promotion and Statistics Division, Ministry of Agriculture and Cooperatives, Kathmandu, Nepal

[5] MoAD 2013. Statistical information on Nepalese Agriculture 2012/13. Agri-Business Promotion and Statistics Division, Ministry of Agriculture Development, Kathmandu, Nepal

[6] NARC (2007) Released and Registered Crop Varietites in Nepal (1960-2007). Communication, Publication and Documentation Division (CPDD), Nepal Agricultural Research Council.

[7] Neupane et al (2011). The effect of seed priming, rhizobium inoculation and nutrient loading on seed yields and nodulation of mungbean. Results form on-farm trials 2010 FORWARD Nepal (unpublished).

[8] Robertson LD, Shrestha R, Francis CM, Piggin C, Pandey R, Gupta MS, Rana PK (1995) 'Collection and conservation of land races of pulses in Nepal.'NARC/ICARDA/CLIMA.

[9] TEPC (2011) Trade and Export promotion center (TEPC). Republica, March 9, 2011.

[10] Darai, R. 2013, Development of Micronutrients (Fe, Zn, Se) Rich Lentils to Improve the Nutritional Security for Better Health in Nepal. 